\title{
ANALYSIS OF SETTLEMENTS DYNAMICS WITHIN KRAMPNA COMMUNE USING GIS
}

\author{
${ }^{1}$ Ihor KOZAK, ${ }^{2}$ Hanna KOZAK \\ 1,2 John Paul II Catholic University of Lublin, Poland \\ ${ }^{1}$ modeliho@kul.lublin.pl
}

\begin{abstract}
The main aim of this work is to analyze the dynamics of settlements from the 2nd half of the 18th century to 2nd half of 20th century in Krampna commune (Krępna), in Jasło district, Podkarpatske voivodeship in Eastern Poland. Krampna commune was analyzed in terms of the changes of settlements, applying maps together with published historical data for the analysis of changes in its structure. Firstly, the tactical map of «WIG- Military Institute of Geography» was applied. Secondly, maps from the "WMS-Web Map Service, Geoportal" were analyzed. Changes in the number of villages and households population dynamics for Greek Catholics, Latins and Jews for the year 1785 were evaluated applying ArcGIS 10.3 program. Ukrainian ones were evaluated using ArcGIS 10.3 program in comparison with the number of Poles and Jews for the year 1939. Religious and ethnic composition from the 2 nd half of the 18 th century to 2 nd half of 20 th century and the character of settlements distribution in Krampna commune was evaluated based on the study of spatial distribution of settlements with the use of Spatial Statistics (Spatial Autocorrelation Global Moran's test, Standard Deviational Ellipse and Mean Centre). In 1785 there were 95,69\% of Greek Catholics and in 1939 there were 96,18\% of Ukrainians in Krampna commune. There was confirmed a similar configuration of Standard Deviation Ellipse and Mean Center for Greek Catholics who were Ukrainians for the year 1785 and Ukrainians for the year 1939 in Krampna commune. The scale and results of such changes are essential for future research, mainly in terms of the change of traditional village system infrastructure and culture.
\end{abstract}

Key words: dynamics, village, GIS, Krampna commune.

DOI: https://doi.org/10.17721/2413-7154/2017.78.5-10

UDC: $911.3+528.9$

\section{АНАЛІЗ ДИНАМІКИ ПОСЕЛЕНЬ ҐМІНИ КРАМПНА ІЗ ЗАСТОСУВАННЯМ ГІС}

\author{
'Iгор КОЗАК, ${ }^{2}$ Ганна КОЗАК \\ 1,2Люблінський католицький університет ім. Йоана Павла II, Польща \\ ${ }^{1}$ modeliho@kul.lublin.pl
}

\begin{abstract}
Анотація: Головною метою статті було дослідити линаміку поселень від другої половини 18 до другої половини 20 століття ґміни Крампна (Krępna) Ясільського повіту Підкарпатського воєводства південно-східньої Польщі. У статті проаналізовано характер розміщення поселень, кількість сіл, чисельність господарств, релігійний та національний склад в актуальних межах ґміни Крампна. На початку аналізовано карти WIG - Військового Інституту Географії, а також WMS-Web Map Service із Геопорталу. Зміни чисельності поселень, кількості господарств, чисельності греко-католиків, латинників і євреїв станом на 1785 рік було оцінено із застосуванням програми ArcGIS 10.3. Також у цій програмі станом на 1939 рік проаналізовано чисельність українців порівняно із чисельністю поляків та євреїв. Особливості релігійного та етнічного складу населення гміни Крампна від другої половини XVIII до другої половини XX століття, а також характер розміщення поселень у гміні оцінено на основі просторового аналізу поселень із застосуванням просторової статистики (глобальна просторова кореляція Морана, еліпс стандартних відхилень та середній центр). Показано, що у 1785 році на території ґміни Крампна домінували греко-католики, які займали 95,69\%, а у 1939 році переважали українці (96,18\%). Встановлено подібну конфігурацію еліпсів стандартних відхилень та середніх центрів тяжіння для греко-католиків у 1785 році і українців у 1939 році у межах ґміни Крампна. Виявлено зміни традиційних сільських систем (ТСС) та культурних надбань у межах ґміни Крампна. Масштаб і результати таких змін $є$ важливими для подальних досліджень, особливо в аспекті дослідження змін традиційних сільських систем, їх інфраструктури та соціально-культурних надбань.
\end{abstract}

Ключові слова: динаміка, поселення, ГІС, ґміна Крампна.

DOI: https://doi.org/10.17721/2413-7154/2017.78.5-10

UDC: $911.3+528.9$

Formulation of scientific problem. Statistical data is not always objectively shown in terms of ethnic and religious composition of the whole Galicia population [14] and the study area of Krampna commune. Based on this situation, it may be considered that evaluation of national origins and religious data

(C) I. Kozak, H. Kozak is quite significant for a research within Krampna commune. Abovementioned is also important in terms of rural cultural landscapes. Such cultural landscapes are usually associated with traditional village system (TVS) with centre-periphery zoning from houses, gardens and fields, mowed and grazed grasslands to forests [9]. The consequences of losing such a system require a more detailed study. 
Analysis of last research of this problem. The dynamics of settlements in Krampna commune was not a subject to any research. There may be identified studies on specific religious and ethnic relations within the Polish-Slovak-Ukrainian borderlands [12], landscape change at high Beskid (Bieszczady) [21], historical aspects of Polany village [1] and three-dimensional reconstruction of already nonexisting tserkvas [18]. The analysis of the literature on traditional village systems (TVS) shows how such systems contribute to characteristic natural and cultural heritage [4]. Cultural heritage of TVS has been recognized and promoted at a global level in a number of international agreements and programmes $[6 ; 10 ; 19]$. However, the traditional village system with its cultural landscape is often threatened by socio-economic and technological changes in agriculture, industrial forestry and by particular nature conservation strategies $[4 ; 6]$. The role of TVS in terms of Ukrainian Carpathians is evaluated in the context of sustainable forest management [9]. The analysis of the social and cultural aspects of TVS is a current issue and requires development of new approaches.
Formulating goals of the article. The aim of this work is a detailed study on settlement distribution within present borders of Krampna commune. Additionally, it is important to conduct the analysis of the loss of TVS and of evidence of the change in ethnic, religious and cultural components.

Materials and methods. Settlements in the landscape within current borders of Krampna commune, in Jaslo county, Podkarpatske voivodeship (in Polish - gmina Krampna, powiat Jaselski, województwo Podkarpackie) were objects of this study.

Historical material from 1785, archival materials, geo-statistical methods of research available in modern GIS packages were used. The study of the dynamics of settlements was performed by applying their location in the form of points and polygons on maps from 1785 and 1939. The corresponding layers in the ArcGIS 10.3 program $[16 ; 19]$ were completed. The number of these householders [14] and the number of inhabitants based on religious and ethnic composition was added for each of these settlements, starting from $2^{\text {nd }}$ half of the $18^{\text {th }}$ century, especially from 1785 [8] and from 1939 [14]. Tactical map of «WIG- Military Institute of Geography» and maps

Table. 1

Religious and national distribution of settlements in Krampna commune.

Based on Z. Budzyński [8] and V. Kubijovyč [14] data

\begin{tabular}{|c|c|c|c|c|c|c|c|}
\hline & \multirow{2}{*}{$\begin{array}{l}\text { Name } \\
\text { in English, Ukrainian, Polish }\end{array}$} & \multicolumn{3}{|c|}{1785} & \multicolumn{3}{|c|}{1939} \\
\hline & & Greek Catholics & Latins & Jews & Ukrainians & Poles & Jews \\
\hline 1 & Tychania, Тиханя, Ciechania & 305 & 0 & 7 & 425 & 5 & 0 \\
\hline 2 & Hrab, Граб, Grab & 450 & 0 & 9 & 680 & 40 & 0 \\
\hline 3 & $\begin{array}{l}\text { Huta Polyanska, Гута Полянська, Huta } \\
\text { Polańska }\end{array}$ & - & - & - & - & - & - \\
\hline 4 & Kotan, Котань, Kotań & 213 & 0 & 10 & 345 & 5 & 0 \\
\hline 5 & Krampna, Крампна, Krępna & 440 & 0 & 6 & 620 & 125 & 5 \\
\hline 6 & Mystsova, Мисцова, Myscowa & 1023 & 0 & 10 & 1310 & 10 & 0 \\
\hline 7 & Ostryshne, Остришне, Ostryszne & - & - & - & - & - & - \\
\hline 8 & Ozhynna, Ожинна, Ożenna & 395 & 0 & 3 & 360 & 0 & 0 \\
\hline 9 & Polyany, Поляни, Polany & 678 & 115 & 11 & 1225 & 60 & 5 \\
\hline 10 & Rozstajne, Розстайне, Rostajne & 280 & 0 & 8 & 320 & 0 & 10 \\
\hline 11 & $\begin{array}{l}\text { Svyatkova Mala, Святкова Мала, Świątkowa } \\
\text { Mała }\end{array}$ & 205 & 0 & 4 & 320 & 0 & 0 \\
\hline 12 & $\begin{array}{l}\text { Svyatkova Velyka, Святкова Велика, } \\
\text { Świątkowa Wielka }\end{array}$ & 528 & 0 & 14 & 820 & 5 & 5 \\
\hline 13 & Vyshevatka, Вишеватка, Wyszowadka & 240 & 0 & 0 & 245 & 0 & 5 \\
\hline 14 & $\begin{array}{l}\text { Svirzhova Ruska, Свіржова Руська, Świerzowa } \\
\text { Ruska }\end{array}$ & 266 & 30 & 6 & 475 & 5 & 0 \\
\hline 15 & Zhydivske, Жидівське, Żydowskie & 310 & 0 & 7 & 405 & 5 & 10 \\
\hline & Sum & 5333 & 145 & 95 & 7550 & 260 & 40 \\
\hline
\end{tabular}

- lack of data 
from the «WMS-Web Map Service, Geoportal» were applied. Changes in number of villages and households population dynamics for Greek Catholics, Latins and Jews for the year 1785 were evaluated applying ArcGIS 10.3 program. Ukrainian ones were evaluated using ArcGIS 10.3 program in comparison with the number of Poles and Jews for the year 1939. Ethnic and religious composition from the $2^{\text {nd }}$ half of the $18^{\text {th }}$ century to $2^{\text {nd }}$ half of $20^{\text {th }}$ century and the character of settlements distribution in Krampna commune was evaluated, based on the study of spatial distribution of settlements with the use of Spatial Statistics (Spatial Autocorrelation Global Moran's test, Standard Deviational Ellipse and Mean Centre) executed in ArcMap program [20].

The main material of the research. Calculations in the present work, conducted on the basis of data published by $\mathrm{Z}$. Budzyński [8], evidence that in the Krampna commune in 1785 Greek Catholic (Ukrainians) population amounted to $95.69 \%$, Latins to $2.60 \%$ and Jewish to $1.70 \%$ (Tab. 1). However, it should be noted that Z. Budzyński by the term Latins, except Poles, meant also Ukrainians, who spoke Ukrainian language, however in order to participate in mass service went to the church (kościół). As a result, the term "Latins" is incorrect. A correct manner is to identify two different terms: Roman Catholics (Poles) and Latins (Ukrainians), as it had been done before [14]. The previous is well illustrated on the example of such villages as: Sviezova Ruska, and Polyany. In 1785 in the village of Sviezova Ruska there lived 266 Greek Catholics and 30 Latins according to Z. Budzynski [8]. According to Kubiiovych in 1939 there lived 475 Ukrainians and 5 Poles [14]. In 1785 in the village of Polyany there lived: 678 Greek Catholics, 115 Latins and 11 Jews [8], while in 1939 there lived 1225 Ukrainians, 5 Jews and 60 Poles
[14]. That decrease of number of Poles in statistics for the year 1939 confirms the inaccuracy of data presented by Z. Budzyński. Consequently, Ukrainian dominance is quite clear, meaning the dominance of Greek Catholics and Ukrainians (Tab. 1) in Krampna commune is confirmed by the following data analysis from the year 1939, when $96,18 \%$ of commune's population were Ukrainians, 3,31\% were Poles and $0,51 \%$ were Jews (percentage of Germans was lesser than $001 \%$ and therefore was not analyzed in the present publication).

This situation demonstrates the dominance of Ukrainians before World War II. The placement ellipses analysis (Fig. 1) showed that in 1785 ellipse for Greek Catholics (black) is broader and covers a large area. This indicates a natural and more equilibrist distribution of Greek Catholics within Krampna commune. The ellipse for Latins was not possible to create since Latins were living only in two villages (115 people in Polyany and 30 people in Svirzhova Ruska villages). The mean center for Greek Catholics (black square) shows a more central distribution comparing to the mean center for Latins (grey triangle), which was located within $5.2 \mathrm{~km}$ to the North-East in comparison to the mean center of Greek Catholics. The ellipse for Jews (grey line) and mean center (grey hexagon) shows a similar central distribution comparing to the ellipse and the mean center representing of Greek Catholics.

The analysis of obtained results of Moran's test leads to the conclusion that there was random distribution of religion composition in the year 1785 - for Latins. In case of Greek Catholics and Jewish population the Moran's test has shown dispersed distribution and confirmed that the probability of their distribution being a result of randomness is less than $10 \%$.

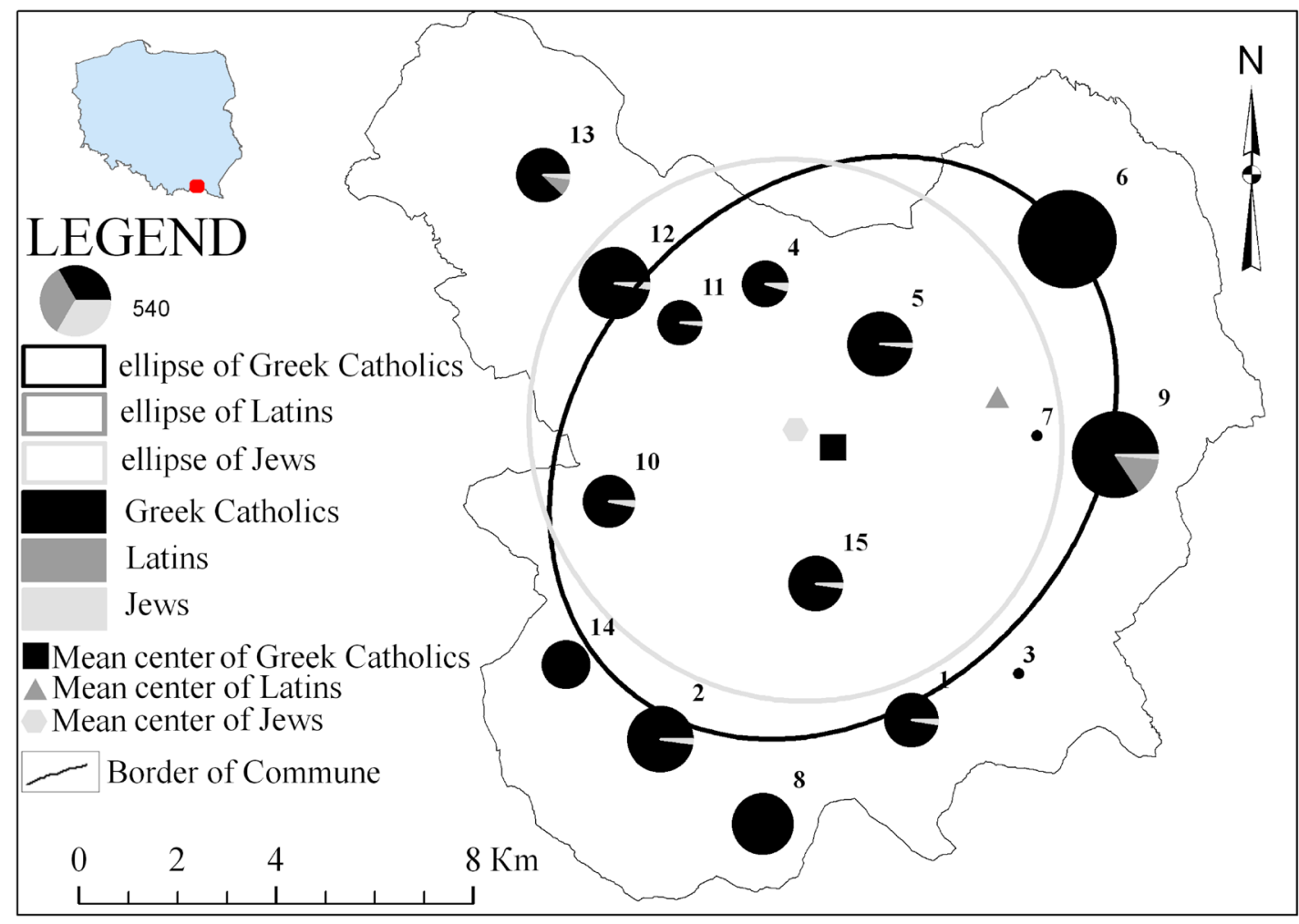

Fig. 1. Religious structure of settlements in Krampna commune in 1785. Own research based on Z. Budzyński data [8]. 
In all settlements of Krampna commune (numbers on the figures correspond to settlement number and settlement name in the table) Greek Catholics dominated in 1785. After the year 1785, the number of Greek Catholics increased [7]. In 1939 (Fig. 2) distribution ellipse for Ukrainian (black) did not changed in comparison with ellipse for Greek Catholics in the year 1785. This tendency confirms the stability and durability of their settlement on the territory of Krampna commune.

In 1939 ellipse for Poles (dark-gray) is smaller, elongated oval (Fig. 2) and distributed more to the NorthEast, comparing to the ellipse for Ukrainians (black). Ellipse representing Jews (light-gray) moved to the West. Mean centre (gray hexagon) representing Jews moved to the West and mean centre representing Poles (gray triangle) moved to the East.

The analysis of Moran's test results leads to the conclusion that there was random distribution of ethnic composition in the year 1939 - for Poles and Jews. Only in case of Ukrainian population, the Moran's test has shown dispersed distribution (Index Moran's for Ukrainians = $-0,478664 ; Z=-1,684100 ; \mathrm{P}=0,092162)$ and confirmed that the probability of their distribution being a result of randomness is less than $10 \%$.

All settlements within Krampna commune area were destroyed. Complete $(100 \%)$ destruction of households occurred in such villages as: Tychania, Ostryshne, Rozstajne, Svyatkova Mala, Svyatkova Velyka, Vyshevatka, Zhydivske, Svirzhova Ruska. In many others settlements, the level destruction reached over $80 \%$. It should be noted that the level of destruction that occurred in 1950's was the highest and contributed to the loss of traditional village system.
The comparison of the data from the year 1939 and 1965 showed a sharp decrease in the number of households. Analysis of the number of households proved that in 1939 there were 1177 households on the Krampna commune territory. In 1965, the number of households fell sharply to 331 units.

Before World War II the area of Krampna commune was densely populated. In 1785 density level reached 27,38 persons for $1 \mathrm{~km}^{2}$. In 1939 density level reached 38,56 person for $1 \mathrm{~km}^{2}$. According to the Central Statistical Office of Poland, density level in the year 2011 decreased to 9,84 persons for $1 \mathrm{~km}^{2}$ [16] (2004 persons; 1059 men and 945 women on the area of $203,58 \mathrm{~km}^{2}$ ).

In 1875 in Krampna commune there lived 5573 people. The majority of them, therefore 5333 out of 5573, were Ukrainian Greek Catholics. In 1939 there lived 7850 people in the commune, including 7550 of Ukrainian nationality. In the year 1965 the population of commune amounted to 1250 people with no Ukrainians among them. Analyzing this situation, it is clear that without Ukrainians Krampna commune has lost the traditional village system, rich in cultural, social and economic traditions.

Before World War II the character of traditional land use practices (two field rotating system, a combination of tillage and livestock products in one sector, crops rotation, mechanical devices for cultivation and weed control, protection of soil from erosion using special methods of plowing) was completely dependent on the availability of local natural sources and kept in a sustainable and balanced relationship with the environment and with minimal use of resources and energy of the region [2]. Rural settlement livelihoods reflect spatial-temporal form of organization of life. These settlements were inherent

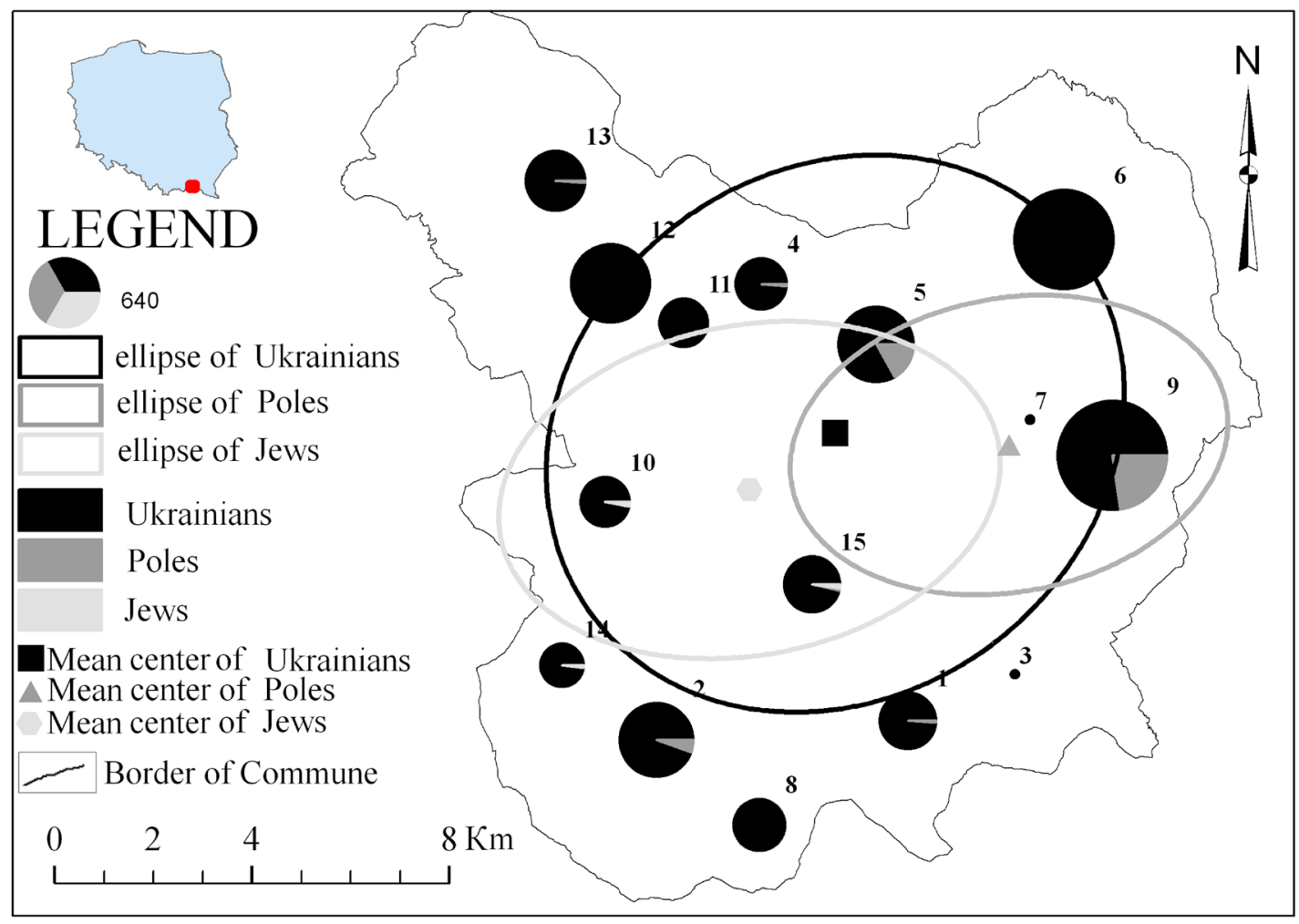

Fig. 2. National structure of settlements in Krampna commune in 1939. Own research based on V. Kubijovyč data [14]. 
with traditional way of building for villages, features of wooden architecture, location and structure of agricultural land. Rural life was the basis of Ukrainian ethnographic identity.

After World War II the Krampna commune was depopulated. The area of buildings, arable land, pastures and grasslands decreased. The structure of the land and forests has changed dramatically. The private forests and lands were transferred to the state property. Since 1951 there have been made attempts to settle these territories by seasonal workers or even people who had problems with the law [15]. Economic activities carried after 1950's were not always consistent with traditional systems management. Seasonal work caused an influx of people from different parts of Poland to Beskid, nonetheless they usually left that area after the work season.

These changes reduced the variety of structural elements such as hedges and gardens, individual trees in various areas of traditional village system. People that moved into the commune from low-lying areas, till these days do not feel the spirit of that place (genius loci), spirit of this mountainous area. The local use of natural resources should be considered as a weakness. There are no satisfying practices of traditional land use. As it was shown by SWOT (Strengths, Weaknesses, Opportunities and Threats) analysis for Krampna commune, currently there may be identified unfavorable conditions for its development, such as: little access to historical documentation, no tradition and therefore connection with its origins, no indigenous population, lack of access to religious sites (other than Roman Catholic), inconvenient architectural forms as to the landscape conditions.

Names of villages, which originally came from Ukrainian etymology, were changed into Polish: Krępna appeared instead of the name Krampna (from the name of ukr. «крам» - goods), Ożenna instead of Ozhynna (from the name of ukr. «ожина» - blackberry), Ciechania instead of Tychania, Wyshowadka instead of Vyshevatka, Grab instead of Hrab. At present time, on the territory of Krampna commune there does not exist any link between generations. Villages that had been the core of Ukrainian traditional village systems (TVS), together with tserkvas and chapels in the center of village, roadside crosses, traditional farms and households were lost. The Lemko Ukrainian tserkva, that dominated on the area of the commune, are considered as sacred and unique monuments of national wooden architecture, preserved in the center of old Rutenian traditions and became an element of Ukrainian and European cultural and religious foundation. Ukrainians have always preserved their cultural values (in every tserkva, except religious icons, there were also icons of Prince Volodymyr and Princess Olga, to whom Ukrainians prayed and with whom they linked their confidence and hope). Tserkva, due to its form and building material, perfectly inscribed into the landscape and complemented it.

In Krampna commune there were 13 tserkvas, located in the following villages: Krampna - tserkva of Kosma and Damyan from 1782; Svirzhova Ruska - tserkva of Ivan Chrestytel from 1894; Hrab - tserkva of Kosma and Damyan from 1809; Svyatkova Velyka - tserkva of Archanhel Myhayil from 1757; Svyatkova Mala - tserkva of Archanhel Mychail from 1700; Mystsova - tserkva of St. Paraskeva from 1796; Polyany - tserkva of St. Ivan Zolotoustyj from 1900; Kotan - tserkva of Kosma and Damyan from 1800; Ozhynna - tserkva of Vasylij Velykyj from 1867; Rozstajne - tserkva of Kosma and Damyan from 1600; Tychanya - tserkva of St. Mykolaj from 1790; Vyshevatka - tserkva of (unknown name) from 1700; Zhydivske - tserkva of Voznesinnya Chrysta from 1828.

After deportation of Ukrainians, there remained only 6 out of 13 tserkvas in Krampna commune in Svyatkova Velyka, Svyatkova Mala, Mystsova, Polyany, Kotan, Krampna that currently were taken over by the Roman Catholic church [13]. Four tserkvas in villages of Hrab, Rozstajne, Tychanya and Zhydivske were destroyed during or immediately after the deportation of Ukrainians in the years 1945-1947. Three tserkvas in villages of Svirzhova Ruska, Vyshevatka, Ozhynna were demolished in the postwar period - during 1950's.

Tserkvas, as spiritual centers, were located mainly on hills (the highest part) in the central area of the settlements. Settlements were one street structured, in chained form, where buildings were built with one roof, therefore reflecting the ethnographic peculiarities of Ukrainian settlement and their life [2].

After deportation of Ukrainians it is difficult to consider settlements as those that perform traditional role of rural systems. In fact, destroyed TVS had the traditional spatial structure, satisfying different needs of people. Research shows that lack of such system negatively affects the social and cultural aspects of sustainable management of the studied region. After World War II, there has been noticed in the region an increase in forestation and decrease in land use (due to decrease in number of population within that area). Eventually, natural succession process took advantage over the lack of human activity and land use practices [5]. Objective historical information on loss of traditional village system (TVS) is also important for touristic purposes. Analyzing the value of the landscape after the deportation of Ukrainians on the example of former Ruthenian (Ukrainian) Boryslavka village (currently nonexistent) in Sanotsko-Turchansky mountains (Podkarpatske voivodeship, Pshemysl county, Fredropol commune), A. Affek [3] confirmed the sudden and radical changes in the characteristics of most landscape: the loss of its identity, the loss of spirit of the place (genius loci) of mountain terrain [3].

According to the European Landscape Convention [10] - it is a loss of social and cultural values on local and regional level. The Convention defines landscape as zone or area in the perception of local residents or visitors, where visual signs and symbols of the landscape are a result of natural and cultural factors, historical stratifications for a long time. The most important - its identity, tradition and material culture in the human landscape [10]. Those elements where lost in the Krampna commune. The abovementioned conducts to the degradation of the landscape, which in our opinion, constitutes a coherent entity, where natural and cultural components are closely interrelated.

Conclusions. Analysis of changes of settlement structure in Krampna commune confirms the dominance 
of Greek Catholics $(95,69 \%$ in 1785) and Ukrainians (96,18\% in 1939). Analysis of ellipses and mean centers for Greek Catholics in 1785 and Ukrainians in 1939 presents steady and identical settlements within Krampna commune.

In summary, it is worth noting that after 1947 the number of households has decreased. The structure of the landscape, nature of traditional farming, TVS, that have been formed for centuries, have changed.
Signs of Ukrainian identity, such as tserkvas, considered as spiritual center of Ukrainians in Krampna commune completely disappeared.

The changes analyzed on the example of Krampna commune are typical for the PolishUkrainian border. The scale and consequences of such changes require further research, especially in terms of the traditional village system and its cultural heritage.

\section{References:}

1. Ardan B. Moï ridni Polâny. Štryhy do istorï sela [My Polyany. History of the village]. L'viv, 2011,140 p. (In Ukrainian).

2. Utrysko M. Etnohrafični doslidžennâ Boykivščyny miž dvoma vijnamy [Ethnographic research of Boikivshchyna between the two wars] LB (E). CH 2/40 (51), 1984, pp. 1-15. (In Ukrainian).

3. Affek A. Wartości krajobrazu opuszczonego przez ludność na przykładzie byłej Rusińskiej wsi Borysławka. Prace Komisji Krajobrazu Kulturowego. Nr 15, 2011, pp. 148-160. $267 \mathrm{p}$.

4. Agnoletti M. The Conservation of Cultural Landscapes. CAB International, Wall-ingford and New York, 2006,

5. Ambrozy S. Wika S. Kierunki sukcesji zbiorowisk roślinnych z olszą szarą Alnus incana (L) Moench na gruntach porolnych w Bieszczadach Zachodnich, Prace instytutu badawczego leśnictwa, Seria A, 1998, Nr 855, pp. 104-142.

6. Antrop M. Why landscapes of the past are important for the future. Landscape Urban Plann, 2005, №70, pp. $21-34$.

7. Blażejowskyj D. Historical Šematism of the Eparchy of Peremyśl' . Lviv: Kameniar, 1995, 1008 p.

8. Budzyński Z. Ludnośc pogranicza Polsko-Ruskiego w drugiej Polowie 18 wieku. Przemyśl - Rzeszów, 1993, 489 p.

9. Elbakidze M. Angelstam P. Implementing sustainable forest management in Ukraine's Carpathian mountains: the role of traditional village systems, Forest Ecology and Management, 2007, №249/1, pp. 28-38.

10. European Landscape Convention. European Treaty, Council of Europe, 2000, N. 176, 7 p.

11. Gil A. Deportacja Ukraińców z Polski w latach 1944-1946 jako problem w aktualnych stosunkach PolskoUkraińskich. Lublin: Wydawnictwo Instytutu Europy Środkowo-Wschodniej, 2004, 30 p.

12. Holly G. Stosunki wyznaniowe i narodowościowe na pograniczu polsko-słowacko-ukraińskim. Roczniki Bieszczadzkie, 2014, N. 15, pp. 179 -207.

13. Iwanusiw O. Church in Ruins: The demise of Ukrainian churches in the eparchy of Peremyshl, St. Catharines: St. Sophia, 1986, 354 p.

14. Kubijovyč V. Ethnic groups of the South-Western Ukraine (Galyčyna-Galicia) 1.1.1939. München: Logos, 1983, 217 p.

15. Luboński P. Przewodnik Bieszczady. Bocz, 2015, 268 p.

16. GUS. Stan i struktura ludności. Baza Demograficzna, 2011 [electronic source]. Access mode: http://demografia. stat.gov.pl/BazaDemografia/ [Accessed 11.03.2017].

17. Skorowidz Map. 1:100 000 [electronic source]. Access mode: http://igrek.amzp.pl/mapindex.php?cat=WIG100. [Accessed 11.03.2017].

18. Stępień A., Kozak I., Kozak H. Trójwymiarowa rekonstrukcja obiektu architektoniczno-krajobrazowego na przykładzie nieistniejącej cerkwi w Bieniowej (Bieszczady Zachodnie). Roczniki Bieszczadzkie, 2011, №19, pp. 379-387.

19. UNESCO, Evaluations of cultural properties. International Council on Monuments and Sites (ICO-MOS). UNESCO, WHC-99/CONF.209/INF.7. Marrakesh, Morocco, 1999, 188 p.

20. Urbański J. GIS w badaniach przyrodniczych. Gdańsk: Wydawnictwo Uniwersytetu Gdańskiego, 2010, 266 p.

21. Wolski J. Transformations of the high Bieszczady Mountains rural landscape during the last 150 years. Warszawa: IGiPZ PAN im. S. Leszczyckiego, 2007, 228 p. 